University of Nebraska - Lincoln

DigitalCommons@University of Nebraska - Lincoln

Agronomy \& Horticulture -- Faculty Publications

Agronomy and Horticulture Department

$9-1984$

\title{
In Vitro and In Vivo Analyses of Hays of Switchgrass Strains Selected for High and Low In Vitro Dry Matter Digestibility
}

\author{
K. P. Vogel \\ United States Department of Agriculture, kvogel1@unl.edu \\ R. Britton \\ University of Nebraska-Lincoln \\ Herman J. Gorz \\ United States Department of Agriculture \\ Francis A. Haskins \\ University of Nebraska-Lincoln, fhaskins@neb.rr.com
}

Follow this and additional works at: https://digitalcommons.unl.edu/agronomyfacpub

Part of the Plant Sciences Commons

Vogel, K. P.; Britton, R.; Gorz, Herman J.; and Haskins, Francis A., "In Vitro and In Vivo Analyses of Hays of Switchgrass Strains Selected for High and Low In Vitro Dry Matter Digestibility" (1984). Agronomy \& Horticulture -- Faculty Publications. 267.

https://digitalcommons.unl.edu/agronomyfacpub/267

This Article is brought to you for free and open access by the Agronomy and Horticulture Department at DigitalCommons@University of Nebraska - Lincoln. It has been accepted for inclusion in Agronomy \& Horticulture -Faculty Publications by an authorized administrator of DigitalCommons@University of Nebraska - Lincoln. 


\title{
In Vitro and In Vivo Analyses of Hays of Switchgrass Strains Selected for High and Low In Vitro Dry Matter Digestibility ${ }^{1}$
}

\author{
K. P. Vogel, R. Britton, H. J. Gorz, and F. A. Haskins ${ }^{2}$
}

\begin{abstract}
In a previous report the progress made in altering the in vitro dry matter digestibility (IVDMD) of switchgrass (Panicum virgatum $\mathbf{L}$.) in one cycle of divergent selection was described. In this study, the detergent system of analyses was used in an attempt to determine what plant constituents had been altered by the selection for IVDMD. Hays from five switchgrass strains differing in IVDMD harvested over a 3-year period were analyzed for protein content, neutral detergent fiber (NDF), acid detergent fiber (ADF), ash, and lignin. Although there were differences $(p \leq 0.05)$ among strains for IVDMD as determined by two different procedures (with and without additional $N$ ), there were no differences among strains for ADF, ash, lignin, and protein. The strains ranked the same with the two IVDMD procedures but the IVDMD-N (with additional $\mathbf{N}$ ) test averaged 6.7 percentage points higher in digestibility. There were small differences $(p \leq 0.1)$ among strains for NDF in 2 of the 3 years. The strain with the highest IVDMD had the lowest NDF, suggesting that, in part, the improved IVDMD was due to a decrease in the cell wall component of the harvested forage. Hays of three of these strains, high-IVDMD PC, low-IVDMD PC, and 'Pathfinder' from the 1980 harvest were ground and fed to sheep to compare in vivo and in vitro digestibilities. After grinding, the hays had IVDMD-N values of 49.9, 45.5, and $46.7 \%$, respectively. There were no differences among strains in the sheep feeding trial for in vivo digestibility, dry matter intake, and fiber digestibility. The in vivo digestibilities for these strains were: highIVDMD PC 50.4\%, low-IVDMD PC 49.0\%, and Pathfinder 50.8\%. In contrast to a previous report in the literature, the IVDMD$\mathrm{N}$ values were generally similar to in vivo digestibilities for switchgrass hays. Parameters of the conventional detergent system of analyses, while useful in identifying factors responsible for changes in digestibility of switchgrass hays, would probably be of little value as selection criteria in a breeding program. Because of the large number of animals required to obtain statistical significance in in vivo digestibility studies, the IVDMD procedure would be preferable in studies in which breeding material is being evaluated and small differences in digestibility are expected.
\end{abstract}

Additional index words: Panicum virgatum L., IVDMD, NDF, ADF, Lignin, Forage quality, Protein.

Cwitchgrass (Panicum virgatum L.) is a warmseason $C_{4}$ grass that is native to the prairies and plains of North America. In a previous report Vogel et al. (1981) described the progress made in altering the in vitro dry matter digestibility (IVDMD) of switchgrass in one cycle of divergent selection. Over the 2 years of their study, the strains with the highest and lowest IVDMD differed by 3.4 percentage units when harvested at heading. These strains were selected from the same Nebraska experimental population and were similar in maturity and forage yield.

In the detergent system of analyses, the neutral detergent fiber (NDF) fraction consists of the cell wall component of the forage, and acid detergent fiber is the cell wall component minus the hemicelluloses (Van Soest and Robertson, 1980). Lignin and ash contents are self-explanatory. The cell contents, which are the most easily digested components of the forages, are soluble in the neutral detergent solution. Improved digestibility of a forage can be achieved by either decreasing the cell wall component of the forage or increasing the digestibility of the cell wall or both.

Both the detergent system of analyses and the IVDMD procedure were developed and evaluated with cool-season $\mathrm{C}_{3}$ grasses and there is evidence that both sets of procedures are less predictive of animal performance when used to analyze warm-season $\mathrm{C}_{4}$ grasses (Griffin et al., 1980; Lippke, 1980; Abrams et al., 1981). In the genus Panicum there are both $\mathrm{C}_{3}$ and $\mathrm{C}_{4}$ grasses, and the difference in the anatomical structures of the $\mathrm{C}_{3}$ and $\mathrm{C}_{4}$ grasses is reported to be responsible for the higher in vitro digestibilities and lower cell wall content values obtained with the $C_{3}$ grasses (Wilson et al., 1983; Akin et al., 1983). Among the $\mathrm{C}_{4}$ Panicums, Wilson et al. (1983) found significant differences for leaf dry matter digestibility and cell wall contents. Switchgrass had higher leaf dry matter digestibility than most of the $\mathrm{C}_{4}$ Panicums evaluated (Wilson et al., 1983).

${ }^{1}$ Contribution from the Nebraska Agric. Exp. Stn. and the USDA-ARS. Published as Paper no. 7365, Journal Series, Nebraska Agric. Exp. Stn. Received 5 Dec. 1983.

${ }^{2}$ Research geneticist, USDA-ARS; Professor, Dep. of Animal Science; supervisory research geneticist, USDA-ARS; and George Holmes professor of agronomy, Univ. of Nebraska, Lincoln, NE 68583 . 
Table 1. In vitro forage quality parameters of five switchgrass hays harvested in 3 consecutive years at Mead, NE.

\begin{tabular}{|c|c|c|c|c|c|c|c|c|c|}
\hline \multirow[b]{2}{*}{ Strain } & \multicolumn{9}{|c|}{ Means $\ddagger$} \\
\hline & IVDMD & IVDMD-N & Protein & $\mathrm{NDF}$ & $\mathrm{ADF}$ & Lignin & Ash & $\begin{array}{c}\text { Summative } \\
\text { equation } \\
\text { digestibility }\end{array}$ & $\begin{array}{c}\text { Forage } \\
\text { DM } \\
\text { yield }\end{array}$ \\
\hline \multicolumn{9}{|c|}{ 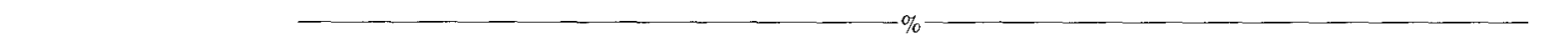 } & $\mathrm{Mg} \mathrm{ha}^{-1}$ \\
\hline \multicolumn{10}{|c|}{1978} \\
\hline High IVDMD PC & 47.2 & 56.2 & 9.8 & 72.5 & 40.5 & 7.2 & 3.8 & 57.3 & 7.36 \\
\hline High IVDMD OP & 45.3 & 51.6 & 9.5 & 72.4 & 40.0 & 7.1 & 2.8 & 57.3 & 7.44 \\
\hline Pathfinder & 45.6 & 51.1 & 9.4 & 73.8 & 40.8 & 7.4 & 3.1 & 56.5 & 7.10 \\
\hline Low IVDMD OP & 43.8 & 49.5 & 9.3 & 73.5 & 40.9 & 7.1 & 3.1 & 57.7 & 7.80 \\
\hline Low IVDMD PC & 43.3 & 51.4 & 9.7 & 73.1 & 40.4 & 7.4 & 3.3 & 56.4 & 7.32 \\
\hline $\operatorname{LSD}_{0.05} \dagger$ & 1.7 & 2.5 & 0.3 & NS & NS & NS & NS & NS & NS \\
\hline \multicolumn{10}{|c|}{1979} \\
\hline High IVDMD PC & 55.8 & 60.1 & 10.3 & 77.3 & 39.2 & 5.7 & 2.9 & 61.8 & 9.30 \\
\hline High IVDMD OP & 54.6 & 58.0 & 10.1 & 77.1 & 39.4 & 5.4 & 2.8 & 65.0 & 9.53 \\
\hline Pathfinder & 54.0 & 57.5 & 10.0 & 77.4 & 38.3 & 4.9 & 3.2 & 66.9 & 9.06 \\
\hline Low IVDMD OP & 52.9 & 56.6 & 9.8 & 77.4 & 38.9 & 5.2 & 2.8 & 65.6 & 9.28 \\
\hline Low IVDMD PC & 52.8 & 56.3 & 10.3 & 77.3 & 39.6 & 5.2 & 3.4 & 66.1 & 9.21 \\
\hline $\mathrm{LSD}_{0.05}$ & 1.2 & 2.0 & NS & NS & NS & NS & 0.4 & NS & NS \\
\hline \multicolumn{10}{|c|}{1980} \\
\hline High IVDMD PC & 48.9 & 58.2 & 8.5 & 68.6 & 38.7 & 5.4 & 3.7 & 66.4 & 12.54 \\
\hline High IVDMD OP & 45.0 & 54.0 & 8.0 & 70.2 & 40.1 & 5.9 & 3.3 & 63.9 & 12.54 \\
\hline Pathfinder & 43.6 & 54.0 & 8.0 & 70.2 & 39.7 & 6.0 & 3.8 & 63.5 & 11.72 \\
\hline Low IVDMD OP & 46.1 & 54.6 & 8.3 & 69.6 & 38.8 & 5.8 & 3.8 & 63.4 & 12.63 \\
\hline Low IVDMD PC & 44.1 & 53.9 & 8.1 & 70.3 & 39.6 & 5.8 & 4.3 & 63.8 & 12.54 \\
\hline $\mathrm{LSD}_{0.05}$ & 2.7 & 2.3 & NS & NS & NS & NS & NS & NS & NS \\
\hline
\end{tabular}

+ NS indicates that the $F$ test in the analyses of variance was not significant at the 0.05 level of probability.

$\ddagger$ IVDMD = in vitro dry matter digestibility, IVDMD-N is IVDMD with additional $\mathrm{N}$ added to the incubation tube; $\mathrm{ADF}=$ acid detergent fiber, $\mathrm{NDF}=$ neutral detergent fiber.

In a feeding trial with sheep, Griffin et al. (1980) reported that IVDMD values underestimated the in vivo digestibility of 'Black well' switchgrass hay grown in Pennsylvania and fed to sheep by an average of 17 percentage units. Reid et al. (1982) reported that digestible dry matter of switchgrass hays is consistently higher with cattle than with sheep.

The purposes of this study were to determine what plant constituents had been altered by divergent selection for IVDMD using the detergent system of analyses (Goering and Van Soest, 1970), and to compare the IVDMD results with an in vivo digestibility trial with sheep.

\section{MATERIALS AND METHODS}

The five switchgrass strains used in this study are listed in Table 1 and were described by Vogel et al. (1981). The high- and low-IVDMD strains are based on clones selected from the 'ey $\times \mathrm{ff}$ ' population for high or low IVDMD, respectively, PC indicates that the strains were developed by polycrossing ramets (segments) of selected clones in isolated polycross nurseries while OP indicates that the strain was developed by harvesting open-pollinated seed from the selected clones in the selection nursery. These strains were planied in a replicated sward trial on 18 May 1978 at Mead, $\mathrm{NE}$, as described by Vogel et al. (1981). In brief, the experimental design was a randomized complete block with seven replications. Plots were $4.3 \mathrm{~m}$ long and $1.2 \mathrm{~m}$ wide and were separated on the ends by $1.2-\mathrm{m}$ alleys of 'Pathfinder' switchgrass.

The plots were fertilized with approximately $110 \mathrm{~kg} \mathrm{~N}$ $\mathrm{ha}^{-1}\left(\mathrm{NH}_{4} \mathrm{NO}_{3}\right)$ each year and with $26 \mathrm{~kg} \mathrm{P}^{-1}$ in 1980.

\footnotetext{
${ }^{3}$ Mention of a trademark, proprietary product, or vendor does not constitute a guarantee or warranty of the product by the USDA or the Univ. of Nebraska and does not imply its approval to the exclusion of other products or vendors that may also be suitable.
}

Atrazine [2-chloro-4-(ethylamino)-6-(isopropylamino)-striazine] was used for weed control in 1978 and 1979. In 1979 and 1980, DCPA (dimethyl tetrachloroterephthalate) was also used for weed control. Recommended rates were used for the herbicides.

In 1978, the plots were harvested on 5 September when most of the panicles were emerging from the boot. Switchgrass flowers later in the establishment year than in subsequent years. Plots were harvested with a $\mathrm{Carter}^{3}$ flail type plot harvester at a cutting height of $10 \mathrm{~cm}$. The harvester cut a $0.9-\mathrm{m}$ swath out of the center of each $1.2-\mathrm{m}$ wide plot, chopping the forage into 6 - to $12-\mathrm{cm}$ long pieces. The forage from each plot was weighed and then sampled by taking six grab samples which were composited. The composited samples from each plot were used to determine dry matter content and for the laboratory analyses. In 1979, plots were harvested on 23 July when about one-third of the tillers in the nursery had panicles emerging from the boot. The same harvesting procedure was used as in 1978.

In 1980, the harvesting procedure was modified to obtain the hays used in the in vivo study. On 21 July when the switchgrass panicles were emerging from the boot, the Pathfinder alleys and borders were cut with the plot harvester and bagged in large burlap bags. Each plot was then cut in its entirety with the plot harvester, weighed, and sampled using the same procedure as in previous years, and then bagged in large burlap bags. Entire plots were harvested to increase the amount of hay available for the in vivo study. The bagged hay samples were dried at $50^{\circ} \mathrm{C}$ in forced air dryers. Prior to feeding to sheep, they were ground through a $3.8-\mathrm{cm}$ screen.

In each year of the study, the samples for laboratory analyses were dried in a forced air oven at $65^{\circ} \mathrm{C}$ and ground in a Wiley mill to pass a $1-\mathrm{mm}$ screen. The samples were analyzed for IVDMD using two different methods. The first method, which we shall designate simply as IVDMD, was essentially the basic Tilley and Terry (1963) procedure ex- 
cept that $\mathrm{HgCl}_{2}$ and $\mathrm{Na}_{2} \mathrm{CO}_{3}$ were not added after the first stage digestion. Rumen fluid was taken from two animals on different diets and bulked on an equal volume basis. One animal was maintained on a low-quality forage while the other was on a high-quality forage. The animals and the specific rations varied from year to year. In 1978 and 1979 , duplicate IVDMD analyses were made and the means of both analyses are reported. In 1980, a single analysis was made on each sample. The other IVDMD analysis will be designated as IVDMD-N since additional N ( $15 \mathrm{mg}$ urea/ tube) was added to the digestion fluid. Forage sample size was $300 \mathrm{mg}$. In the IVDMD-N procedure, rumen fluid was obtained and combined from steers fed alfalfa (Medicago sativa L.) hay or a corn (Zea mays L.) cob diet, strained through four layers of cheese cloth, placed in a warm thermos and transferred to the laboratory. Rumen fluid was diluted 1:1 with artificial saliva (McDougall, 1948) and used for the IVDMD analyses.

The samples were analyzed for crude protein (percent $\mathrm{N} \times 6.25$ ) using the Kjeldahl procedure (A.O.A.C., 1960). The samples were analyzed for neutral detergent fiber (NDF), acid detergent fiber (ADF), lignin ( $\mathrm{KMnO}_{4}$ procedure), and ash using procedures described by Goering and Van Soest (1970). Summative equation digestibilities were calculated by the procedure described by Goering and Van Soest $(1970)$.

In the in vivo study, 24 wether lambs were randomly assigned to the three switchgrass treatments. The lambs were housed in individual crates and during the trial were fitted with fecal collection bags. Fresh water was available at all times and the temperature of the feeding room was maintained at $19^{\circ} \mathrm{C}$. Because of the small quantity of hay available from the high- and low-IVDMD PC strains, the sheep were fed the Pathfinder switchgrass hay from the alleys and borders and from the high-and low-IVDMD OP strains for 8 days prior to the initiation of the trial. Pathfinder and the high- and low-IVDMD PC strains were then evaluated in the feeding trial. Treatment hays were fed for 9 days and fecal collections were taken daily the last 6 days of the trial. Sheep were fed $800 \mathrm{~g}$ of the ground switchgrass hay daily. Orts were collected daily, weighed, dried, and composited for fiber and dry matter determinations. Feces were dried in a forced air oven at $60^{\circ} \mathrm{C}$ for $48 \mathrm{~h}$. Feces and orts were analyzed for fiber using the same techniques used for the forage. Based on fiber analyses of the orts, no sorting of the original forage was observed. In vivo dry matter digestibility, dry matter intake, and fiber digestibility (NDF) were then calculated using standard procedures. The data were analyzed using analyses of variance procedures for a randomized complete block for the individual years and as a split-plot-in-time for the combined analyses.

\section{RESULTS AND DISCUSSION}

In each of 3 years of the study there were significant differences among the switchgrass strains for both IVDMD and IVDMD-N (Table 1). The highIVDMD PC strain was consistently higher in IVDMD and IVDMD-N than the other strains. The strains tended to rank in the order listed for in vitro digestibility as determined by either method although there were some exceptions. In each year of the study, there were no apparent visual differences among strains for maturity or leafiness; therefore, the observed differences in IVDMD are probably true differences in the digestibility of the forage and are not due to maturity or yield effects. The IVDMD-N values averaged 7.0 ,
Table 2. In vivo digestibilities, dry matter intake, and fiber digestibility of switchgrass hays differing in IVDMD.

\begin{tabular}{|c|c|c|c|c|c|}
\hline \multirow[b]{2}{*}{ Strain } & \multicolumn{5}{|c|}{ Means } \\
\hline & IVDME-N & Protein & $\begin{array}{c}\text { In vivo } \\
\text { dry matter } \\
\text { digesti- } \\
\text { bility }\end{array}$ & $\begin{array}{l}\text { Dry } \\
\text { matter } \\
\text { intake }\end{array}$ & $\begin{array}{c}\text { Fiber } \\
\text { digesti- } \\
\text { bility }\end{array}$ \\
\hline & \multicolumn{3}{|c|}{$\longrightarrow \%$} & $\mathrm{~g}$ & $\%$ \\
\hline High IVDMD PC & 49.9 & 6.8 & 50.4 & 683 & 55.9 \\
\hline Pathfinder & 45.5 & 6.8 & 50.8 & 718 & 57.0 \\
\hline Low IVDMD PC & 46.7 & 6.8 & 49.0 & 674 & 54.1 \\
\hline \multicolumn{6}{|c|}{ Other statistics } \\
\hline \multirow{2}{*}{\multicolumn{3}{|c|}{$\begin{array}{l}\text { 'F' } \\
\text { Probability level of ' } F \text { ' }\end{array}$}} & 0.90 & 2.43 & 1.62 \\
\hline & & & 0.42 & 0.11 & 0.22 \\
\hline \multicolumn{3}{|c|}{$\mathrm{CV} \%$} & 5.8 & 6.1 & 5.5 \\
\hline
\end{tabular}

3.7, and 9.4 percentage units higher than the IVDMD values in 1978,1979 , and 1980 , respectively.

There were no significant differences $(p \leq 0.05)$ among the strains in any of the three years for percent protein, NDF, ADF, lignin, or ash except for small differences in protein content in 1978 and ash content in 1979. In 1978 and 1980 , however, there were differences among strains for NDF at the 0.11 and 0.06 levels of probability, respectively. The NDF $\operatorname{LSD}_{0.1}$ values for 1978 and 1980 were 1.0 and 1.1 , respectively. In the combined analyses over years, there were small differences among strains for NDF $(p=0.06)$. There were significant differences among strains $(p \leq 0.05)$ over years for IVDMD and IVDMD$\mathrm{N}$ but not for any of the other traits. The highIVDMD PC strain had the lowest NDF and highest IVDMD over the 3-year period. This suggests that the high IVDMD strain is higher in in vitro digestibility at least in part due to a decrease in cell wall contents of its forage. Summative equation digestibilities were higher than either the IVDMD or IVIMDD-N values, and they were inconsistent in ranking the strains for digestibility. Thus, in this study, the detergent analysis parameters, except for possibly NDF, did not support the observations based on the IVDMD procedure.

Both IVDMD and IVDMD-N values were higher in 1979 than in 1978 or 1980 even though NDF values were higher in 1979 than in the other two years. The low lignin content in 1979 may have been responsible for the higher digestibility for that year, i.e., the cell walls may have been more digestible.

The hay that was fed to the sheep was ground before feeding to reduce selectivity and hay wastage since the amount of hay available for the trial was limited. The IVDMD-N values after grinding (Table 2) were lower than those prior to grinding (Table 1, 1980 data) possibly due to leaf loss during grinding. The high-IVDMD strain, however, was still 3 and 4 percentage units higher in IVDMD-N than the lowIVDMD PC and Pathfinder strains, respectively. Although the high-IVDMD strain had numerically higher in vivo digestibility, dry matter intake and fiber digestibility than the low IVDMD strain, these differences were not significant (Table 2). The differences among strains in IVDMD-N did not result in significant differences in in vivo digestibility under the conditions of this feeding trial. Our results do indicate that the IVDMD-N values are approximately 
the same as the in vivo digestibilities obtained with sheep. This is in agreement with the results of McLeod and Minson (1969) with other warm-season grasses but differs from the results of Griffin et al. (1980) on switchgrass.

In summary, both IVDMD procedures could probably be used to rank switchgrass hays for digestibility. The IVDMD-N values are more representative of the in vivo values obtained with sheep. Parameters of the conventional detergent system of analyses, while useful in identifying the factors responsible for changes in the digestibility of switchgrass hays, would probably be of little value in identifying switchgrass genotypes with improved digestibilities in a breeding program. Because of the large number of animals required to obtain statistical significance in in vivo studies, the IVDMD procedure would be preferable in studies for which breeding material is being evaluated and small differences in digestibility are expected.

\section{REFERENCES}

1. Abrams, S.M., H. Hartadi, C.M. Chaves, J.E. Moore, and W.R. Ocumpaugh. 1981. Relationship of forage-evaluation techniques to the intake and digestibility of tropical grasses. Proc. 14 Int. Grassl. Congr. 14:508-511.

2. Akin, D.E., J.R. Wilson, and W.R. Windham. 1983. Site and rate of tissue digestion in leaves of $\mathrm{C}_{9}, \mathrm{C}_{4}$, and $\mathrm{C}_{3} / \mathrm{C}_{4}$ inter- mediate Panicum species. Crop Sci. 23:147-155.

3. Association of Official Agricultural Chemists. 1960. Official methods of analyses of the A.O.A.C. 9th ed. Washington, DC.

4. Goering, H.K., and P.J. Van Soest. 1970. Forage fiber analyses: apparatus, reagents, procedures, and some applications. USDA-ARS Agric. Handb. 379. U.S. Government Printing Office, Washington, DC.

5. Griffin, J.L., P.J. Wangsness, and G.A. Jung. 1980. Forage quality evaluation of two warm-season range grasses using laboratory and animal measurements. Agron. J. 72:951-956.

6. Lippke, H. 1980. Forage characteristics related to intake digestibility and gain by ruminants. J. Anim. Sci. 50:952-961.

7. McDougall, E.I. 1948. The composition and output of sheep's saliva. Biochem. J. 43:99-109.

8. McLeod, M.N., and D.J. Minson. 1969. Sources of variation in the in vitro digestibility of tropical grasses. J. Br. Grassl. Soc. 24:244-249.

9. Reid, R.L., L.C. Vona, and G.A. Jung. 1982. Nutrient intake and mineral adequacy of subtropical grasses. Agron. Abstr. Am. Soc. of Agron. Madison, WI. p. 153.

10. Tilley, J.M.A., and R.A. Terry. 1963. A two stage technique for in vitro digestion of forage crops. J. Br. Grassl. Soc. 18:104111 .

11. Van Soest, P.J., and J.B. Robertson. 1980. Systems of analyses for evaluating fibrous feeds. p. 49-60. In W.J. Pigden, C.C. Balch, and M. Graham (ed.) Standardization of analytical methodology for foods. Int. Development Res. Ctr., Ottawa, Canada.

12. Vogel, K.P., F.A. Haskins, and H.J. Gorz. 1981. Divergent selection for in vitro dry matter digestibility in switchgrass. Crop Sci. 21:39-41.

13. Wilson, J.R., R.H. Brown, and W.R. Windham. 1983. Influence of leaf anatomy on the dry matter digestibility of $\mathrm{C}_{3}, \mathrm{C}_{4}$, and $\mathrm{C}_{3} / \mathrm{C}_{4}$ intermediate types of Panicum species. Crop Sci. 23:141-146. 